\title{
KAMPUNG PULO: \\ Traces of Islamic Culture in Garut Regency, West Java
}

\author{
By Abdul Syukur*
}

\begin{abstract}
Abstrak
Cangkuang merupakan salah satu tujuan wisata di Kabupaten Garut. Ada banyak tempat dan atraksi wisata di Desa Cangkuang, yaitu Danau (Situ), Candi Hindu, Museum, Kuil Arif Muhammad dan masyarakat tradisional yang dikenal sebagai Kampung Pulo; Itu semua menjadi agenda satu paket wisata bagi agen perjalanan. Kampung Pulo juga dikenal sebagai Kampung Adat karena masyarakatnya masih mempertahankan kebiasaan atau tradisi yang mereka warisi dari nenek moyang mereka. Mereka, misalnya, dilarang untuk melanggar beberapa larangan seperti menambah jumlah rumah menjadi enam dan ada tribun dan anyaman bambu untuk dinding dalam model; melakukan pesta dengan musik menggunakan suara gong; sistem pewarisan harus matrilineal, dan sebagainya. Selain itu, orang-orang dari Kampung Pulo mengklaim bahwa mereka adalah keturunan Arif Muhammad yang, seperti pada umumnya mengatakan, seorang penyebar agama Islam di wilayah itu. Sebagai misionaris Muslim yang menarik telah meninggalkan beberapa naskah yang sekarang disimpan di museum di sebelah Kampung Adat.
\end{abstract}

Kata kunci: masyarakat tradisional; pariwisata; budaya Islam

\section{Introduction}

Kampung Pulo in Cangkuang village is known as one of traditional communities in Garut regency. It is called traditional because its population is still strongly hold customs or a tradition. That is why Kampung Pulo is also called "Kampung Adat." The Customs or traditions of Kampung Pulo are believed to be handed down from their ancestor, namely Arif Muhammad. Kampung Pulo or "Kampung Adat" complex, grave of Arif Muhammad, together with a small temple and Lake Cangkuang now become one of tourists' destinations from within and outside the country as well as pilgrims.

The fact that the "Kampung Adat" is located on an island (Sundanese: pulo), namely the island of Panjang (Pulo Panjang), which once surrounded by water of the lake and completely separated from the other islands, then the region is called

\footnotetext{
* Lecturer in Religious Studies Department, Faculty of Ushuluddin, State Islamic University (UIN) Sunan Gunung Djati, Bandung. Data of this article come mainly from my research on Tradition Preservation and Related Problems (2005) funded by the Toyota Foundation.
} 
Kampung Pulo for generations. The name has also eventually become the official name in the village administration of Cangkuang.

Besides being regarded as the ancestor of the Kampung Pulo community, who has left descendants and norms that have become their customs, Arif Muhammad was also regarded as the first Muslim missionary in that area. Adat or customs with certain sanctions inherited from Arif Muhammad becomes guidance of people behaviour in Kampung Pulo, and they do not dare to violate them because they believe if they do that they will get in trouble such as having disaster or an accident.

Focus of discussion in this paper is customs or traditions in Kampung Pulo. Nevertheless, the discussion of a tradition cannot be separated from the relation with the origin or the source from which it came. In this case, what which became the origin of the tradition of the community of Kampung Pulo is a story or myth about Arif Muhammad. Besides being a source of tradition Arif Muhammad was also believed to be the propagator of Islam, and as the Islamic missionary he had bequeathed manuscripts or texts about the Islamic religion, which until now are stored and can be read in the museum next to Kampung Pulo complex.

The discussion begins with a description of the Kampung Pulo location within the Cangkuang village. As part of this discussion I will also present about potentials the village has that they can attract people to come there as tourists. Because of such potentials the local government of Garut regency especially has set Cangkuang village as one of the tourist destinations in Garut regency. The discussion continues with an overview of the tradition or customs held by community of Kampung Pulo. Some customs or habits have changed, or even abandoned, but some still remain. There are several reasons that allow a culture might change. The discussion followed by discussing about the story, or more exactly a myth, of Arif Muhammad as the ancestral of Kampung Pulo community, both regarding his roles as the origin of people and as the disseminator of Islam at that time represented by his works as Islamic cultural traces. This paper will conclude with some remarks about the possibility of Kampung Pulo as a tourism destination and the conservation of cultural heritage texts of Islam in Garut regency in the future.

\section{Kampung Pulo as a Tourist Destination}

Leles square sub-regency. Buses, microbuses, cars, motorcycles, bicycles, horse-drawn carriages and other public transportation are milling about around the Leles sub-regency square which is located on the edge of the roadway between Bandung and Garut. In the corner of the square facing west from which usually 
tourists come stands a large signpost indicating direction to Situ Cangkuang (Lake of Cangkuang) and stating it as a tourist's attraction.

Road with width no more than five meters is full twists and makes the vehicle run winding and creeping because the driver must be alert at every turn. Because of such circumstances tourist big buses are difficult to pass, but buses of three-quarters in size. They also must compete with other road users. In some places there are even a very sharp bend so the driver of the vehicle should be really careful and restrain the rate of vehicle. Except for bicycles and motorcycles one precedes another vehicle nearly impossible, and if by chance two rather large vehicles are passing each other then they should wait to give an opportunity to and let another pass.

Peeling asphalt makes the road dusty and perforated. Stones are scattered everywhere and gaping holes can be seen here and there. As a result, during rainy season these holes are forming small pools of brownish water because the water is mixing with the soil. ${ }^{1}$ In such circumstances, every driver of bicycles, motorcycles and horse-drawn carriages should try to control their vehicle to avoid puddles and not to make a splash to other road users. With the patience to accept such condition of the road then we will come to Kampung Ciakar, a small area also belonging to the Cangkuang village administration, as the gate to Situ (lake) Cangkuang and Kampung Pulo. ${ }^{2}$

The village of Cangkuang is geographically located in sub-regency (kecamatan) Leles, Garut regency. As a village Cangkuang has area borders. There is Neglasari village of Kadungora sub-regency in the north; in the south it borders with Sukarame and Margaluyu villages of Leles sub-regency; in the east it borders with Karang Anyar and Tambak Sari villages of Leuwigoong sub-regency; while in the west there are Talagasari village of Kadungora sub-regency and Leles village of Leles subregency.

Cangkuang village is about 47 kilometres from Bandung, the capital province of West Java, and 17 kilometres from Garut city centre. To reach the village of

\footnotetext{
${ }^{1}$ The road is better now because it has undergone resurfacing.

${ }^{2}$ Due to continuous silting process some small islands have been united. It was formerly impossible and not allowed to take vehicle such as motorcycle and bicycle to Kampung Pulo because Pulau Panjang on which the Kampung is was separated from the village mainland. Now the Pulau Panjang is already connected to the outer edge of the Situ and there is a pathway so that visitors riding motorcycle or ojek are not necessary to come to and park their vehicles in Ciakar and take a raft (rakit) across the Situ to reach Kampung Pulo, they may take a walk or just ride through to Kampung Pulo and park vehicles next to Kampung Pulo complex.
} 
Cangkuang, one may use private vehicles or public transportation such as buses. The buses pass by to and from Garut, Bandung and Jakarta. However, public transport such as buses will let one just get off next to the square of Leles, the capital subregency, and he or she has to travel about 2 kilometres more from the capital subregency. To do that one has to take either horse-drawn carriage (local people call it andong) or motorcycle taxi (ojek) with the fare varies. Along journey one can see people houses and stalls and enjoy seeing view of paddy filed and vegetables plantation. Planting vegetables such as tomatoes and cabbages is an alternative livelihood for people in the sub-regency of Leles and Garut population in general.

"Cangkuang" is a name that is attributed into three different objects, namely the village, the lake, and the temple. In this case, we know the name of Cangkuang village, Lake of Cangkuang (Sundanese people prefer to call it Situ Cangkuang), and Cangkuang temple. The Cangkuang temple is located on the top of an island (Pulau Panjang) in the middle of Situ Cangkuang, while Situ Cangkuang is a part of the Cangkuang village area.

Within Situ Cangkuang, which is approximately 24 hectares in size, there are several small islands, such as Pulau Panjang, Pulau Gede, Pulau Leutik, and others. That is why the local government (pemerintah desa) of Cangkuang states that typology of the village is islands village (desa kepulauan). Community of Kampung Pulo and Cangkuang temple are together located on one of the islands, that is Pulau Panjang within the Situ Cangkuang. Moreover, on that island there is also a sacred tomb and a small building or museum which is used to store archaeological objects. These heirlooms from the past are said to be the inheritance or legacy of Arif Muhammad, a figure which is regarded as the first Muslim missionary in the area. That is one of reasons why many people come to Kampung Pulo. They come as pilgrims to visit the tomb of Muhammad Arif and pray for him beside the tomb. In fact, according to the elders in the Kampung Pulo and others around the Cangkuang village who ever experienced period of revolution, people had come and made a pilgrimage to the tomb of Arif Muhammad long before ruins of the temple were found and reconstructed. At that time Situ Cangkuang was still look like a really large lake in which people around could sail on kajang (twin-boat) or swam to search for various types of fish for the purposes of their daily consumption or supplemental income.

Topographically Situ Cangkuang is in a lush valley between 600-700 meters above the sea level and located at coordinates 106 $54^{\prime} 36.79^{\prime \prime}$ east longitude and $7^{\circ} 06^{\prime} 09^{\prime \prime}$ south latitude. The valley surrounded by a range of mountains such as Mount Haruman (1.218 meters) in the east-north side, Pasir Kadaleman (681 meters) 
in the southeast, Pasir Gadung (1.841 meters) in the south, Mount Guntur (2.849 meters) in the south-west, Mount Malang (1.329 meters) in the west, Mount Mandalawangi in south-north, and Mount Kaledong (1.249 meters) in the east. Because of such a situation Binarwan (2003:78), then, classifies tourism in Cangkuang village into type of natural tourism. But, Cangkuang tourism does not only provide Lake Scene, it also offers others which attract tourists to come. Tourists, therefore, do not come to the Cangkuang village only for enjoying its natural beauty; they also come to see the temple, the museum, Muhammad Arif shrine and the living tradition of Kampung Pulo for generations. Contrary to Binarwan, the local Government of Garut regency, as quoted by Utomo, classifies Cangkuang tourism into "natural and cultural" type. ${ }^{3}$

The combination of various types of tourist attractions in the Cangkuang makes such a categorization of tourism is not easy. Situ Cangkuang scenery with mountain ranges background could attract those who want to enjoy the beauty of nature. Those who are interested in history and archaeological objects, however, the Cangkuang temple and the "museum" may offer them information to increase their knowledge. But those who are interested in tradition and culture, community life in the Kampung Pulo can give additional information. In addition, those who believe in the sanctity of a grave, sacred tomb of Arif Muhammad may become an interesting site to visit. What is important to note here is that the purposes of tourists coming to the Cangkuang are rarely separated each other. Almost all tourists come to the Cangkuang combine all of the above objectives at the same time. So we may say that tourists come to the Cangkuang may enjoy a trip on a raft across the Situ while they look around at the panorama of mountain scenery, and these are followed by visiting the (Hindu) temple of Cangkuang, the tomb of Arif Muhammad, museum and seeing a life of and having nice talk with the community of Kampung Pulo.

Historically, ruins of Cangkuang temple found in December 9, 1966 by Uka Tjandrasasmita, a historical and archaeological researcher and one of a project team about Leles History. The team was led by Prof. Harsojo and sponsored by CV. Haruman belonging to Idji Hatadji. Uka found the temple site precisely when he tried to find an ancient tomb that was mentioned in Notulen Bataviaasch Genootschap (1893) written by Vorderman, a Dutch historian, who mentions about the existence of ancient tomb and statue, not temple, of Linga (Shiva?). His discovery of the temple stones that scattered around the tomb then made Uka to continue seeking for more

\footnotetext{
${ }^{3}$ http://www.budpar.go.id/page.php?ic=543\&id=466
} 
and explore the temple site. Supported by the Government programme, the formerly Department of Education and Culture (Departemen Pendidikan dan Kebudayaan) especially General Directorate of Culture (Direktorat Jendral Kebudayaan) and UNESCO, the temple was reconstructed and named Candi Cangkuang, the first Hindu temple found in West Java.

Since the Laws of Regional Autonomy (Undang-undang tentang Otonomi Daerah or OTDA) issued in 1999 management of tourist attractions in Cangkuang has been meticulous one. The Cangkuang temple, shrine of Arif Muhammad and the Kampung Adat (Pulo) as cultural heritage (cagar budaya) sites used to be under the authority of formerly Department of Education and Culture (Departmen Pendidikan dan Kebudayaan). Along with unifying cultural affairs with tourism the management of these sites was gathered with the Situ Cangkuang under the authority of the Ministry of Tourism and Culture (Kementrian Pariwisata dan Kebudayaan). But, when the cultural affairs were returned to the former these three cultural sites are now back to be under the authority of the Ministry of Education and Culture (Kementrian Pendidikan dan Kebudayaan).

Furthermore, although the Situ is a part of the Garut regency but it is also claimed by the Provincial Government to be under its authority.

As a matter of fact, all these tourist attractions are parts of Garut regency. From the District Government perspective and the regional autonomy regulation, therefore, it should mean that they are under the District authority. However, different claims from different authorities have made the District Government sceptic in managing them. Although The Ministry of Education and Culture and the Provincial Government recognize that the archaeological sites and the Situ are under their authorities but they seem not to be responsible with regard to management of the archaeological sites as well as the Situ. Almost all the sites officers are complained about amount of their salary and method of payment which is not paid every month. ${ }^{4}$ The Situ is almost never dredged by the Provincial Government. ${ }^{5}$ Due to sedimentation of mud brought by streams of Cicapar river and growth of water hyacinth (eceng gondok) is a very fast so the Situ is getting more and more shallow.

\footnotetext{
${ }^{4}$ Today there are eight officers from Balai Pelestarian Cagar Budaya (BPCB) Region IV Serang in Banten. Previously they were volunteers and got salary based on three-monthly payment. Now they all have been formally public servants and have monthly salary paid directly through their own bank accounts.

5 According to some informants the Situ had been dredged twice by the Provincial Government but never completed, and anyway it has been a long time.
} 
The District Government, on the other hand, attracts the admission money to everyone visiting all sites through Tourism and Culture Service (Dinas Pariwisata dan Kebudayaan) officers, but the revenue is nothing to do with the management of archaeological sites as well as the Situ.

The District Government willingness to make Cangkuang village, which is including management of the three archaeological sites in Kampung Pulo and the Situ, as one of the tourist destination related undoubtedly to its program to increase the Regency Government income through the tourism industry, ${ }^{6}$ and increasing local income through the tourism industry seems closely related to the Garut image of the old days (tempo doeloe). It is said in one website that once within its history Garut had earned the nickname "Switzerland van Java." This nickname was given during the colonial era by the Dutch who mesmerized by the beauty of scenery and cool air of the mountains in Garut. The website also reported that according to Frans, the owner of the craft akar wangi Zocha which became one of the special souvenirs from Garut, Queen Beatrix, Queen Wilhelmina family and Charlie Chaplin has been to Garut. Charlie Chaplin, moreover, came to Garut up to two times and had a favourite place to view the beauty of the city that is from the Papandayan mount. During in Garut, which was around 1930, Chaplin stayed at Grand Hotel in Ngamplang. It was also said that Garut is the city in West Java in which the first five-star hotels, Belvedere and Hengel Hotels, were built by the Dutch. This is due to how interested the Dutch colonial on the beautiful scenery and cool air in the region of Garut. Unfortunately, the favourite place being spot seeing for Chaplin (tempat panyawangan si Chaplin) on top of the mountain has now been converted into a golf course and the ruins of the two hotels are not more able to be recognized (dinapak-tilasi) again. ${ }^{7}$

\section{People, Tradition and Related Changes}

Arif Mohammed also appeared to have left descendants who now live partly in Kampung Pulo. They live in houses with the typical shape and a mosque, or because of small size people call it musholla. They become a colony within traditionally Sundanese social system called "kampong". They are the people who for generations hold the customs that have been handed down by their ancestors in

\footnotetext{
${ }^{6}$ In Garut Travel Handbook (2005) issued by the Department of Tourism and Culture of Garut Regency there are 31 alternative places of tourist destination in Garut, and among them hot spring complex in Cipanas to be excellent and the mainstay.

7http://rwisnu.multiply.com/journal/item/1/Swiss_van_Java_dan_Candi_Cangkuang. See also Warjita (2013:6).
} 
the place which is called Kampung Pulo, because they live on the island or "pulo" in Sundanese term in the middle of Situ Cangkuang. Traditionally living according to the customs have made their life unique and because of this uniqueness of the Kampung Pulo tourists come to the Kampung in Cangkuang village.

The Kampung Pulo complex consists of six houses in two rows of pairs. At the west end of the rows there is small building for praying called musholla. This number of six houses with one mosque (musholla), totalling seven, represents the number of children that Arif Muhammad ever had. They were six girls and one boy.

Each house is occupied by a family. Assuming every family consists of more or less six people, the total population of Kampung Pulo then amounted to approximately 36 people. It is interesting that the number of houses should be precisely six, not more or less. But why should it be so? It is said that because Arif Muhammad had six girls and, the youngest, a boy. While the girls lived long and had given birth of their offspring, the only son died in his early life. Now the six houses are representing the number of Arif Muhammad daughters, while the son is represented by a mosque or musholla.

Houses have been inheritance rights (hak waris) for girls. It means that if a wife of one family dies, her husband should go out and the house now belongs to their daughter respectively. If a family, however, does not have any daughter then the inheritance rights of the house goes to the wife sister or to her sister offspring.

If there is a daughter of one family marries a man, she and her husband are allowed to stay in her parent house in the Kampung Pulo for a maximum period of two weeks. ${ }^{8}$ But, after two weeks they have to get out from the house in the Kampung Pulo. But, if she gets the rights and wants then she and her family may return to the Kampung Pulo. Otherwise, her other sisters will have and do.

Arif Muhammad loosing the only son was not without any cause. It is said that once when the boy was at about the age for circumcision Arif Muhammad was about to circumcise his son. The boy was carried on a stretcher (tandu) that has a jure shaped roof (sisi atap berbentuk segi empat) and paraded by music using a gong. Unfortunately, something bad happened, heavy rain with storm came that resulted in the stretcher was carried away and blown into the air by the wind so that the boy to be circumcised fell down. The boy did not only fall down but he also eventually

\footnotetext{
${ }^{8}$ Among Sundanese people, or Indonesian society in general, a wedding ceremony is usually held at the bride's family home and, therefore, it is a custom that the newly married couples stay first at home of women parents until they are provided with a separated house or they buy a their own or rent one.
} 
died. This incident made Arif Muhammad sad very much, ${ }^{9}$ and because of this he then forbade his descendants not to make a party with music using a gong in any celebration, not to build a house with jure shaped roof but jolopong (atap memanjang) and the number of houses had to remain six.

In addition, he forbade his descendants to build a house with the ground floor, i.e. directly upon the soil, but it must be in the form of panggung. In other words, they should build a house which has pillars stand on stone stilts (tatapakan) so that its floor which is usually made from wooden boards is over the soil. Furthermore, the soil made tile (genteng tanah) is also forbidden. The house roof must be made of sago palm leaves (rumbia). Again, the house may not use electric lighting and toilet should not be made inside or united with the house, but it should be separated from the main building.

Other customary rules which are not allowed to maintain are to keep fourlegged animals, except cats. For those who want to raise a four-legged animal, like a goat or buffalo, they can do that outside the Kampung Pulo. Therefore, in Kampung Pulo one may find only two-legged animals such as chickens or ducks. People of Kampung Pulo strive to comply with all the provisions because they believe that any violation of these provisions, as they say, will inevitably lead to disaster or to have an accident.

Also, they are not allowed to work and other people to make a pilgrimage on Wednesday. Kuncen (religious caretaker) will not serve anyone from/or outside Kampung Pulo who come to pilgrim on that day. Work and pilgrimage on Wednesday are forbidden because Arif Muhammad used to preach or convey the teachings of Islam on Wednesdays. So, Wednesday is like a holiday in which people and particularly Arif Muhammad offspring should not go to their farms but learn Islamic religion.

As noted above, custom or tradition in Kampung Pulo contains of a number of restrictions and compulsions. Today, some of them are preserved carefully, such as the number and form of the house. The inheritance rights for girls are also still maintained. Times, however, have already changed. Therefore, some customs or traditions prevailing in Kampung Pulo have also changed.

One informant, for example, stated that in the past time there were really a lot of rules concerning people behaviour and attitudes during in the Kampung Pulo.

\footnotetext{
${ }^{9}$ It is common among Indonesian people, especially men or husbands, which largely based on patrilineal system (decent which is traced through the male line) to expect to have a son as a successor of the family lineage.
} 
These rules used to apply to both the descendants of Arif Muhammad living in or outside Kampung Pulo and the outsiders who came to Kampung Pulo for certain purposes. He remembered once among of these prohibitions that people were not to use umbrellas, sandals and a hat. They were also not allowed whistling, singing, spitting, dating and overstepping the tomb of Arif Muhammad. However, except the last, now these restrictions are no longer applicable.

Within the community life itself some customs or traditions have also already changed. Difficulty in getting sago palm leaves for the house roof, for example, has made them forced to change it with the soil tiles. Only structures of the house inhabited by the Ketua Adat which is still retained its authenticity because it has been made as a model for example. Moreover, similar to the houses of family outside the Kampung Pulo, now each house in Kampung Pulo also uses electric lighting. They even use the available electricity power for the purposes of electronic tools they have such as radio, TV, video-player, refrigerator, and others.

\section{Myth of Arif Muhammad}

As mentioned above that Uka found the temple site when he was trying to find an ancient tomb that was mentioned in Vorderman book of Notes Bataviaasch Genootschap Vorderman. The book does not say anything about whom was buried in the tomb, but it really says "Nabij Mohamedaansche Graven" (Munawar, 2002:71). The people, however, whenever they are asked about it they generally say that the tomb found by Uka is one in which Arif Muhammad was buried. In other words, they believe that one who is inside it is Arif Muhammad body.

Although the book is nothing to do with Arif Muhammad they apparently refer to another source for their argument. They say that there is a manuscript found in Kropak of Karangpawitan in which name of Arif Muhammad is mentioned.

Seeking for another source as an alternative to the fact that the book of Notulen does not mention the name of Muhammad Arif is a creative way and that is, though not entirely, successful. The manuscript undoubtedly says about Arif Muhammad, but it does not mention anything about Mataram sultanate from which Arif Muhammad came as most people believe and are used to tell. It also mentions the "queen cakrawati Nusa Jawa," but it does not say anything about Garut or Cangkuang, let alone Kampung Pulo. The most interesting thing is the fact that the manuscript describes genealogy of (Sultan) Arif Muhammad. It says that he was from Mecca and was in a direct line of the Prophet Muhammad descent, something beyond Kampung Pulo people imagination who usually claims to be Arif Muhammad descendants. If 
they are all Arif Muhammad descendants and Arif Muhammad was a descendant of the Prophet Muhammad then they must be descendants of the Prophet Muhammad too, a conclusion that they never claim.

However, as it also happens to other traditional communities, the Kampung Pulo people historical truth about who was buried in the shrine of Arif Muhammad is not important. They just accept and believe what is said by their parents and ancestors. According to Campbell myth is always concerning things that "outside men's knowledge" and as a response to it (Campbell, 1968:21). Instead of thinking of phenomena that are clearly beyond the limits of the mind people tend to take it with their heart in the form of belief. Even so, according to Eliade (1968:16) myth can be studied because it reveals something that it has really happened, and because it becomes foundation of the structure of reality and its manifestation is creative and exemplary myth also becomes a model for human behaviour. In other words, myth describes the structure of reality and that its ultimate values have to be followed by those believe in it in their real lives.

History of Arif Mohammed is often described by people of Kampung Pulo and other people as a person who came from Mataram Sultanate. He was appointed by Sultan Agung to fight the Dutch army in Batavia in the early 17th century. Unfortunately, the Mataram army attack failed. Having failed to attack the Dutch Arif Muhammad felt disappointed and embarrassed to go back to the Mataram Sultanate. Eventually, instead of going back to the Mataram he looked for another place to live. He then arrived at what is now called the Cangkuang village, precisely in Pulau Panjang in the middle of the Situ Cangkuang, and he decided to stay there for the rest of his life. It was in Pulau Panjang he had a family and left children and grandchildren who then became his descendants.

Decision of not returning to Mataram also means the decision to stop being a soldier. But as a Muslim from Islamic Kingdom he felt obligated to spread Islam in the place where he lived. It is said that people are generally still Hindus or Buddhists. It is not clear if it is any connection or not between Arif Muhammad and the Hindu temple found by Uka. What it is clear people say that Arif Muhammad was later to be known as the first propagator of Islam in the village and its surroundings. ${ }^{10}$

\footnotetext{
${ }^{10}$ Edi S. Ekadjati in his article titled 'Pendidikan di Tatar Sunda pada Periode Islam (2)' in Pikiran Rakyat (November 22, 2004) states that during Islamization in Sundanese area Arif Muhammad was one of important figures. He also states that there are two interesting things from educational system in the early days of Islamization in the area. First, since the Demak
} 
Similar story can also be found in Subang regency that is a story about Ranggadipa in sub-regency of Pagaden and Goparana in sub-regency of Sagalaherang. The two tombs of them are now considered being sacred and often visited by pilgrims. The difference is if Goparana tomb being sacred because he was considered as the first Muslim missionary in that area the sacredness of Ranggadipa is due to he was a Mataram soldier who, though unsuccessful, had tried to attack the Dutch in Batavia. ${ }^{11}$

According to some informants, the Situ Cangkuang was initially a place of ablution for Muslims which was created by Arif Muhammad by stemming water of Cicapar that flows through the area. Meanwhile, the temple is damaged because of the Hindu Queen at that time did not accept Islam propagated by Arif Muhammad. But this last information is rejected by Amat, retired officer from the formerly Department of Education and Culture, suggesting that violation of cultural heritage is never tolerated by Islamic teachings.

Arif Muhammad lived in Kampung Pulo. However, although all people of the Kampung Pulo confidently say that they and their children and grandchildren are descendants of Arif Muhammad none of them knows or able to tell with sure who was to be Arif Muhammad wife.

\section{Manuscripts of Arif Muhammad}

As it has been stated before that in addition to being the ancestral community of the Kampung Pulo Arif Muhammad also was the first Islamic missionary in Cangkuang village, generally in Garut regency. That Arif Muhammad was Muslim missionary has been proven by the discovery of religious texts kept by the Kampung Pulo people.

In fact, the people not only keep the religious manuscripts but also heirlooms from their ancestors. While they are still maintaining heirlooms in their houses they have submitted the manuscripts to Balai Pelestarian Cagar Budaya (BPCB) on behave of the Government. Not less than 16 manuscripts regarded as works of Arif

sultanate (15th and 16th centuries) and the Mataram Sultanate (17th and 18th centuries) the process was pioneered and influenced by many Javanese people and culture; secondly, as in the pre-Islamic era, form of educational institutions were established separately from people lives in which the teacher authority was dominant.

${ }^{11}$ For further information see also Hendra Kadarusman, Tradisi Ziarah di Makam Aria Wangsa Goparana dan Eyang Dalem Ranggadipa di Kabupaten Subang (Bandung, Master thesis in Graduate School of Religious Studies Programme, State Islamic University (UIN) Sunan Gunung Djati, 2011) unpublished. 
Muhammad now preserved in the museum of Cangkuang under the authority of BPCB. Most of these manuscripts have been identified by Balai Pelestarian Cagar Budaya or BPCB (Centre for Cultural Heritage Preservation) Region IV Serang (Banten), ${ }^{12}$ and some others yet. Those identified texts are as follows:

1. Al-Quran manuscript from $17^{\text {th }}$ Century (Naskah Al-Qur'an Abad XVII)

No.

Language

Letter

Text form

Text size

Number of pages

Manuscript materials
: Kmcc 001

: Arabic and Javanese

: Arabic/Pegon

: Essay

: $31.5 \mathrm{~cm} \times 23.5 \mathrm{~cm}$

: 140 pages

: Saeh bark

2. Sermon manuscript from $17^{\text {th }}$ Century (Naskah Khutbah Abad XVII)

No.

Language

Letter

Text form

Text size

Number of pages

Manuscript contents
: Kmcc 002

: Arabic

: Arabic

: Essay

: $167 \mathrm{~cm} \times 23.5 \mathrm{~cm}$

: 1 roll

: The description of the virtues of fasting and alms (zakat fitrah)

3. Fiqih manuscript from $17^{\text {th }}$ Century (Naskah Fiqih Abad XVII)

No.

Language

Letter

Text form

Text size

Number of sheets

Manuscript materials
: Kmcc 003

: Arabic and Java

: Arabic/Pegon

: Essay

: $25 \mathrm{~cm} \times 16.5 \mathrm{~cm}$

: 34 sheets

: Saeh bark

4. Tauhid manuscript from $17^{\text {th }}$ century (Naskah Tauhid Abad XVII)

No.

Language

Letter

Text form
: Kmcc 004

: Arabic

: Arabic

: Essay

12 Balai Pesetarian Cagar Budaya or BPCB, formerly Balai Pelestarian Peninggalan Purbakala (BP3), Region IV Serang (Banten) manages cultural sites in four regencies, namely Garut, Tasikmalaya, Ciamis and Kuningan. 
Text size

Number of sheets

Manuscript materials
$: 25 \mathrm{~cm} \times 17 \mathrm{~cm}$

: 97 sheets

: Saeh bark

5. Fiqih manuscript from $17^{\text {th }}$ century (Naskah Fiqih Abad XVII)

No.

Language

Letter

Text form

Text size

Number of sheets

Manuscript materials
: Kmcc 005

: Arabic and Java

: Arabic/Pegon

: Essay

: $26 \mathrm{~cm} \times 18.5 \mathrm{~cm}$

: 9 sheets

: Saeh bark

6. Nahwu manuscript from $17^{\text {th }}$ century (Naskah Nahwu Abad XVII)

No.

Language

Letter

Text form

Text size

Number of sheets

Manuscript materials
: Kmcc 006

: Arabic

: Arabic

: Essay

: $25 \mathrm{~cm} \times 18 \mathrm{~cm}$

: 73 sheets

: Saeh bark

7. Tauhid manuscript from $17^{\text {th }}$ century (Naskah Tauhid Abad XVII)

No.

Language

Letter

Text form

Text size

Number of sheets

Manuscript materials
: Kmcc 007

: Arabic

: Arabic

: Essay

: $27 \mathrm{~cm} \times 19 \mathrm{~cm}$

: 75 sheets

: Saeh bark

8. Nahwu manuscript from $17^{\text {th }}$ century (Naskah Nahwu dan Sharaf Abad XVII)

No.

Language

Letter

Text form

Text size

Number of sheets

Manuscript materials
: Kmcc 008

: Arabic

: Arabic

: Essay

: $23 \mathrm{~cm} \times 15 \mathrm{~cm}$

: 33 sheets

: Saeh bark

9. Nahwu manuscript from $17^{\text {th }}$ century (Naskah Nahwu Abad XVII) 
No.

Language

Letter

Text form

Text size

Number of sheets

Manuscript materials
: Kmcc 009

: Arabic

: Arabic

: Essay

: $27 \mathrm{~cm} \times 15 \mathrm{~cm}$

: 10 sheets

: Saeh bark

10. Tauhid manuscript form $17^{\text {th }}$ century (Naskah Tauhid dan Fiqih Abad XVII)

No.

Language

Letter

Text form

Text size

Number of sheets

Manuscript materials
: Kmcc 010

: Arabic

: Arabic

: Essay

$: 25 \mathrm{~cm} \times 17 \mathrm{~cm}$

: 28 sheets

: Saeh bark

11. Prayer collection manuscript from $17^{\text {th }}$ century (Naskah Kumpulan Do'a-do'a Abad XVII)

No.

: Kmcc 011

Language

: Arabic

Letter

: Arabic

Text form

: Essay

Text size

$: 13 \mathrm{~cm} \times 9.5 \mathrm{~cm}$

Number of sheets

: 12 sheets

Manuscript materials

: Saeh bark

12. Various prayer manuscript (Naskah Macam-macam Do'a Abad XVII)

No.

Language

Letter

Text form

Text size

Number of sheets

Manuscript materials
: Kmcc 012

: Arabic and Javanese

: Arabic/Pegon

: Essay

$: 12.5 \mathrm{~cm} \times 9 \mathrm{~cm}$

: 17 sheets

: Saeh bark

13. Literature manuscript from $17^{\text {th }}$ century (Naskah Sastra Abad XVII)

No.

Text title

Language

Letter
: Kmcc 013

: Cerita Patih (History of Prime Minister)

: Javanese

: Arabic/Pegon 


$\begin{array}{ll}\text { Text form } & : \text { Essay } \\ \text { Text size } & : 17 \mathrm{~cm} \times 10 \mathrm{~cm} \\ \text { Number of sheets } & : 39 \text { sheets } \\ \text { Manuscript materials } & : \text { Saeh bark }\end{array}$

14. Tauhid manuscript from $17^{\text {th }}$ century (Naskah Tauhid Abad XVII)

No.

Language

Letter

Text form

Text size

Number of sheets

Manuscript materials
: Kmcc 014

: Arabic

: Arabic

: Essay

$: 25 \mathrm{~cm} \times 17 \mathrm{~cm}$

: 48 sheets

: Saeh bark

15. Fiqih manuscript from $17^{\text {th }}$ century (Naskah Fiqih Abad XVII)

No.

Language

Letter

Text form

Text size

Number of sheets

Manuscript materials
: Kmcc 015

: Arabic

: Arabic

: Essay

$: 27 \mathrm{~cm} \times 18 \mathrm{~cm}$

: 34 sheets

: Saeh bark

16. Tauhid manuscript from $17^{\text {th }}$ century (Naskah Tauhid Abad XVII)

No.

Language

Letter

Text form

Text size

Number of sheets

Manuscript materials
: Kmcc 016

: Arabic

: Arabic

: Essay

: $23.5 \mathrm{~cm} \times 14.5 \mathrm{~cm}$

: 52 sheets

: Saeh bark

Notes:

- "Kmcc" stands for "Koleksi Manuscript Candi Cangkuang" (Collection of Temple Cangkuang Museum)

- "Arab/Pegon" means Javanese language written in Arabic script

- "Saeh" is a kind of tree in Kampung Pulo

As can be seen in the description of each manuscript above, all manuscripts of Arif Muhammad preserved in the museum are derived from the $17^{\text {th }}$ century. This means that these manuscripts have been more or less three centuries of age. So, it is 
understood if the manuscripts condition is in a state of obsolescence. In fact there are some texts that cannot be identified anymore.

Fortunately the texts have been saved and now preserved in the museum. Nevertheless, because their condition are vulnerable then the Balai Pelestarian Cagar Budaya (BPCB) as well as other researchers seem to not take the risk to do further research on the content of each manuscript.

\section{Some Remarks}

There are three authorities with regard to the management of tourism in Cangkuang village. They are the Ministry of Education and Culture, in particular Directorate General of Culture, which is responsible to preservation of Kampung Pulo as Kampung Adat, the temple and manuscripts in the "museum"; the provincial Government of West Java which is responsible to the management of Lake or Situ Cangkuang concerning both water preservation and paddy field irrigation; and Garut regency government as the owner of the area which is responsible to its population welfare. The authority of these all institutions will give a positive impact on the development of Kampung Pulo as a tourism destination and, in turn, on the people welfare if each of the institution carries out its responsibility.

On the other hand, if each institution makes its claim but they do not perform what they should it will give bad impact not only on the environment but also local people as a whole. According to Zaki these three institutions have made hands-off impression and they rely on each other with regard to the tourists' objects in Cangkuang village. This is, to my mind; most probably due to lack of clarity about the Regional Autonomy Laws (Undang-undang Otonomi Daerah) which do not state clearly job divisions among three kinds of authority. Consequently, while both the General Directorate of Culture and the Provincial Government assume that those sites are in Garut regency, the Garut District Government is sceptic to manage them. ${ }^{13}$

\footnotetext{
${ }^{13}$ On my last visit there has been a good cooperation between Balai Pelestarian Cagar Budaya (BPCB) with the Local Government of Garut. In addition to all the archaeological sites officers have been public servants the Local Government has also appointed two honorary officers to help them. The BPCB also has expanded the museum building towards the rear so that the visitors are now able to freely look around the ancient manuscripts and other archaeological objects inside the museum. Meanwhile, the Provincial Government apparently has not shown its good intention concerning the Lake or Situ Cangkuang management.
} 
If this situation goes to continue and is not resolved then it is not impossible the environment and cultural sites preservation which becomes the tourists' main attraction, including the preservation of ancient manuscripts which are the traces of Islamic cultural heritage, will be unfinished.

\section{Refferences}

\section{Books:}

Abdullah, Irwan, (eds.). Agama dan Kearifan Lokal dalam Tantangan Global. Yogyakarta: Sekolah Pascasarjana UGM in cooperation with Pustaka Pelajar, $1^{\text {st }}$ print, 2008.

Eliade, Mircea. Myths, Dreams and Mysteries. London and Glasgow: Fontana Library, 1968.

Tourism and Culture Service of Garut Regency. Garut Travel Handbook. Garut: Tourism and Culture Service of Garut Regency. 2005.

Campbell, Joseph. 'The Historical Development of Mythology' in Myth and Mythmaking, Henry A. Murray (ed.). New York: Beacon Paperback. 1968.

Kadarusman, Hendra. Tradisi Ziarah di Makam Aria Wangsa Goparana dan Eyang Dalem Ranggadipa di Kabupaten Subang. Bandung: Master thesis in Graduate School of Religious Studies Programme, State Islamic University (UIN) Sunan Gunung Djati Bandung. 2011, unpublished,

Munawar, Zaki. Cagar Budaya Candi Cangkuang dan Sekitarnya, Garut: self printed. 2002.

Warjita. Sejarah Pembentukan Kota Garut. Garut: CV. Abi Putra. 2013.

\section{Articles in journals, magazines and newspapers:}

Binarwan, Robby. 'Pengembangan Objek Wisata Candi Cangkuang Sebagai Sarana Peningkatan Kesejahteraan Masyarakat' in JIKP. Jakarta: Pusat Penelitian dan Pengembangan Badan Pengembangan Kebudayaan dan Pariwisata. 2003.

Ekadjati, Edi S., 'Pendidikan di Tatar Sunda pada Periode Islam (2)' in Pikiran Rakyat (November 22, 2004).

Kurniawan, Idham, 'PAMA PUJA - the new Indigenous Peoples Organization on Java' in Down to Earth No. 59, November 2003.

Solichudin, Iman, 'Perlindungan Hak Masyarakat Adat' in Pikiran Rakyat (March 23, 2009)

'Situ Cangkuang, Korban Kewenangan' in Pikiran Rakyat (May 17, 2003) 
'Minimnya Informasi Situs Web Pemda' in Pikiran Rakyat (February 23, 2009)

'Situ Cangkuang Menyusut 10 ha' in Pikiran Rakyat (March 30, 2009)

'Fungsi Museum Pudar' in Pikiran Rakyat (February 22, 2009)

'Mitos Burung Blekok (Bangau)' in Gatra (March 12, 2005), pp. 18-19.

'Jalan di Garut Rusak Parah' in Pikiran Rakyat (February 5, 2009) downloaded from http://www.pikiran rakyat.com/index.php?mib=news.detail\&id =57340

\section{Websites:}

http://www.kabarindonesia.com/berita.php?pil=12\&jd=EKSOTISME-OBYEK-

WISATA-GARUT:-Situ-dan-Candi-Cangkuang\&dn=20081124072946

http://www.garut.go.id/pariwisata/index.php?mindex=daf_det_wisata\&id_wisata=1 http://www.budpar.go.id/page.php?ic=543\&id=466

http://www.indoforum.org/showpost.php?p=746808\&postcount=75

http://liburan.info/content/view/309/43/

http://www.budpar.go.id/page.php?ic=541\&id=747

http://www.budpar.go.id/page.php?ic=541\&id=440 